\title{
Intraspecific variations in colour morphs of Hypnea musciformis (Rhodophyta) in relation to nitrogen availability
}

\author{
Aline P. Martins ${ }^{1}$ and Nair S. Yokoya ${ }^{1,2}$
}

Received: 09.12.2009; accepted: 12.08.2010

\begin{abstract}
Intraspecific variations in colour morphs of Hypnea musciformis (Rhodophyta) in relation to nitrogen availability). Effects of nitrate availability in two culture media (von Stosch (VSES), and artificial ASP 12-NTA), and nitrogen sources (seawater enriched with nitrate, ammonium or urea in concentrations ranging from zero to $30 \mu \mathrm{M}$ ) were evaluated in two brown morphs (BR-1, BR-2), one light-green morph (LG) and one dark-green morph (DG) of Hypnea musciformis (Wulfen) J.V. Lamour. Higher growth rates of the four morphs were observed in VSES medium. However, artificial ASP12-NTA medium induced tetrasporangium development in DG morph. Growth rates of the four colour morphs followed kinetic of saturation-type nutrient uptake in treatments with urea. In contrast, growth rates of BR-1, BR-2 and LG morphs were inversely proportional to ammonium concentrations, and those higher than $15 \mu \mathrm{M}$ were lethal. Growth responses of colour morphs of $\mathrm{H}$. musciformis showed intraspecific variations, and they could be used as bioindicators of nitrogen pollution in marine environment by their low tolerance to ammonium.
\end{abstract}

Key words: ammonium, Hypnea musciformis, nitrate, urea

RESUMO - (Variações intraespecíficas em morfos pigmentares de Hypnea musciformis (Rhodophyta) em relação à disponibilidade de nitrogênio). Efeitos da disponibilidade de nitrato em dois tipos de meio de cultura (meio von Stosch (VSES) e meio artificial ASP 12-NTA), e fonte de nitrogênio (água do mar enriquecida com nitrato, amônio e uréia em concentrações de zero a $30 \mu \mathrm{M}$ ) foram avaliados em dois morfos marrons (BR-1, BR-2), um morfo verde-claro (LG) e um morfo verde-escuro (DG) de Hypnea musciformis (Wulfen) J.V. Lamour. As maiores taxas de crescimento dos quatro morfos foram observadas em meio VSES. Entretanto, o meio artificial ASP12-NTA induziu o desenvolvimento de tetrasporângios no morfo DG. As taxas de crescimento dos quatro morfos variaram segundo uma cinética de saturação nos tratamentos contendo uréia. Por outro lado, as taxas de crescimento dos morfos BR-1, BR-2 e LG foram inversamente proporcionais às concentrações de amônio, e aquelas maiores do que $15 \mu \mathrm{M}$ foram letais. As respostas em crescimento dos quatro morfos de H. musciformis apresentaram variações intraespecíficas, e estes morfos podem ser bioindicadores de poluição por nitrogênio em ambientes marinhos devido à sua baixa tolerância ao amônio.

Palavras-chave: amônio, Hypnea musciformis, nitrato, uréia

\section{Introduction}

The genus Hypnea (Gigartinales, Rhodophyta) includes 50 species distributed in warm waters (Masuda et al. 1997), much of them with economic importance in several countries (Critchley \& Ohno 1998). In Brazil, Hypnea musciformis (Wulfen) J.V. Lamour. has a wide geographical distribution, and is the main raw material for carrageenan production (Berchez et al. 1993).

Along the Brazilian coast, populations of Hypnea musciformis usually have a brown phenotype. However, one population composed by brown and dark-green specimens was found in Espírito Santo State. Besides, a brown plant with only one green branch was collected, and a phycoerythrin-deficient morph (light-green phenotype) was originated from this green branch. In laboratory, these specimens were isolated, and cultured in different environmental conditions as irradiance levels, photoperiod, temperature and salinity in order to evaluate if the thallus colour could be an acclimatation to environmental variations. The colour of these $H$. musciformis morphs is a stable characteristic, and is not a result of photoacclimation processes (Yokoya et al. 2003, Martins et al. 2008). The occurrence of

1. Instituto de Botânica, Caixa Postal 3005, 01031-970 São Paulo, SP, Brasil

2. Corresponding author: nyokoya@hotmail.com; nyokoya@pq.cnpq.br 
colour variants in Brazilian red algae was reported to some Gracilaria species, as G. birdiae Plastino \& E.C. Oliveira, G. cornea J. Agardh, and G. domingensis (Kützing) Sonder ex Dickie (Plastino 2003). The first report on colour variants of Hypnea musciformis was described by Yokoya et al. (2003), and the light-green morph was characterized by having lower phycoerythrin concentration, and higher phycocyanin and allophycocyanin concentrations than the brown morph.

The major nitrogen storage pools in macroalgae are amino acids and proteins, and in nitrogen-limited condition, phycoerythrin is an important source of nitrogen (Bird et al. 1982). Then, the colour morphs of $H$. musciformis could be a good experimental systems to study different processes of nitrogen metabolism.

Several approaches on nitrogen metabolism in macroalgae were studied as the effects of nitrogen sources and concentrations (Hanisak 1983, 1990, García-Sanchez et al. 1993, Navarro-Angulo \& Robledo 1999, Pedersen et al. 2004), nitrogen uptake, assimilation and storage (D'Elia \& Deboer 1978, Fujita 1985, Hwang et al. 1987, Andria et al. 1999, Taylor \& Rees 1999, Naldi \& Wheeler 2002, Collén et al. 2004, Martínez \& Rico 2004, Phillips \& Hurd 2004), and the regulation of nitrate reductase activity (Wheeler \& Weidner 1983, Hurd et al. 1995, Lopes et al. 2002, Granbom et al. 2004). Few studies on nitrogen metabolism were conducted with Brazilian macroalgae, except for the uptake of different nitrogen sources in the brown alga Laminaria abyssalis A.B. Joly \& E.C. Oliveira (Braga \& Yoneshigue-Valentin 1994, 1996), the regulation of nitrate reductase activity in red algae Gracilariopsis tenuifrons (C.J. Bird \& E.C. Oliveira) Fredericq \& Hommers (Rossa 1999), Gracilaria birdiae (Donato 2005) and $G$. caudata J. Agardh (Chow et al. 2007), and the effects of nitrate availability in G. birdiae (Costa 2005).

The objectives of our study were to determine the effects of nitrate concentration in different culture media as well as to evaluate different nitrogen sources and concentrations on growth of colour morphs of Hypnea musciformis.

\section{Materials and methods}

Unialgal cultures - Four colour tetrasporophytes of Hypnea musciformis (Wulfen) J.V. Lamour. were selected: two brown morphs (BR-1 and BR-2), one light-green morph (LG) and one dark-green morph
(DG). The LG morph was a phycoerythrin-deficient mutant, and was originated from a green branch, which had arisen probably as a spontaneous mutation in a brown plant (BR-2) collected from Ponta da Baleia, Espírito Santo, Brazil; both morphs were originated by vegetative propagation in laboratory. BR-1 and DG morphs were originated from carpospores liberated, respectively, by brown and dark-green plants collected from Praia de Formosa, Espírito Santo, Brazil. Voucher specimens were deposited in SP herbarium, with the following accession numbers: SP 365645 (LG morph), SP 365646 (BR-2 morph), SP 365671 (BR-1 morph) and SP 365672 (DG morph).

The colour morphs of $H$. musciformis were cultured in sterilized seawater (salinity of 30-32 psu) enriched with von Stosch's solution at half strength (VSES/2, with $250 \mu \mathrm{M} \mathrm{N}$-nitrate) following Edwards (1970) and modified by Yokoya (2000), with vitamin concentrations reduced to $50 \%$. Medium renewal was carried out weekly. Cultures were incubated under $23 \pm 1{ }^{\circ} \mathrm{C}$, irradiance of 30.0-50.0 $\mu \mathrm{mol}$ photons $\mathrm{m}^{-2}$. $\mathrm{s}^{-1}$, provided by cool-white fluorescent lamps with 14:10h light:dark cycle, without aeration.

Nitrogen experiments - Effects of nitrate availability were tested in different culture media: sterilized seawater enriched with von Stosch's solution (VSES), and artificial ASP 12-NTA medium, following Iwasaki (1961), and modified by Yokoya (2000), with different nitrate concentrations (125, 250 and $500 \mu \mathrm{M}$ ) for 28 days. Both culture media presented salinity of $30 \mathrm{psu}$ and $\mathrm{pH}$ of 8.0 .

Effects of nitrogen sources and concentrations: two inorganic nitrogen sources (sodium nitrate and ammonium chloride) and one organic source (urea) were added to sterilized seawater in concentrations of zero, $5,10,15,20,25$ and $30 \mu \mathrm{M}$. Low concentrations of ammonium (zero to $5 \mu \mathrm{M}$ ) were tested in a second experiment to determine the optimal concentrations for growth, as colour morphs did not tolerate higher concentrations of ammonium. Phosphorus was added $\left(\mathrm{Na}_{2} \mathrm{HPO}_{4} \cdot 12 \mathrm{H}_{2} \mathrm{O}\right)$ in concentrations to maintain the $\mathrm{N}: \mathrm{P}$ ratio of $4: 1$. All treatments were prepared with sterilized seawater provided by only one collection, and experimental period was 21 days.

Other experimental conditions were the same as described for unialgal cultures. Each treatment was tested with three replicates, with four apical segments of $10 \mathrm{~mm}$, cultured in $250 \mathrm{~mL}$ Erlenmeyer flasks with $150 \mathrm{~mL}$ of medium. Fresh biomass was recorded weekly in the same intervals of medium renewal. 
Growth rates were calculated as $\left[\ln \left(\mathrm{B}_{\mathrm{f}} \mathrm{B}_{\mathrm{o}}^{-}\right.\right.$ $\left.{ }^{1}\right) \cdot t^{-1}$, where $B_{o}$ is the initial fresh biomass, $B_{f}$ is the fresh biomass after $\mathrm{t}$ days, and $\mathrm{t}$ corresponds to the experimental period (Yokoya et al. 2003).

Data analysis - Data were analyzed by one-way and two-way analyses of variance (ANOVA) and, when normality and equal variance tests did not pass, the data were analyzed by ANOVA on Ranks. Student-Newman-Keuls post hoc test was conducted to distinguish significantly different results $(\mathrm{p}<0.05)$ following the ANOVA tests. Statistical tests were performed by SigmaStat software (version 1.0).

\section{Results}

Nitrate availability in VSES and ASP 12NTA media - The highest growth rates of the four morphs were observed in VSES medium. However, differences among treatments (nitrate concentrations ranging from 125 to $500 \mu \mathrm{M}$ ) were not significant, except for BR-2 morph, which showed the highest growth rate at low nitrate concentration (figure 1). In ASP 12-NTA medium, growth rates of the four morphs were lower than those observed in VSES medium, and the highest growth rates of the BR-1 and DG morphs were observed in low nitrate concentration (125 $\mu \mathrm{M})$ (figure 1). A comparison among the four morphs showed intraspecific variations to the response to nitrate availability (table 1), and DG and LG morphs showed, respectively, the lowest and the highest growth rates in both culture media (figure 2).

The ASP 12-NTA medium stimulated the development of tetrasporangia in DG morph (figure $3 \mathrm{~A}$ ), and specimens cultured under 250 and 125 $\mu \mathrm{M}$ of nitrate became fertile after four and seven weeks, respectively. Some tetraspores germinated "in situ" and tetrasporelings grew on the stichidium (figure 3B), or tetraspores, which were settled onto coverslips placed on the bottom of culture flasks, germinated and gave rise to several tetrasporelings (figure 3C-G).

Effects of nitrogen sources and concentrations - Growth rates of BR-1, BR-2 and LG morphs of Hypnea musciformis cultured with different concentrations of $\mathrm{N}$-nitrate did not vary significantly when compared to the control (figure 4). However, growth rates of DG morph increased significantly under treatments with $\mathrm{N}$-nitrate concentrations from 5 to $30 \mu \mathrm{M}$ (figure 4 ).

Variations of growth rates on the studied morphs with the addition of zero to $30 \mu \mathrm{M}$ of $\mathrm{N}$-ammonium were significantly different (figure 5), except for the DG morph. BR-1, BR-2 and LG morphs showed inverse relationship between growth rates and $\mathrm{N}$-ammonium concentrations, and concentrations equal and higher than $15 \mu \mathrm{M}$ were lethal for $\mathrm{LG}$ and BR-2 morphs, respectively.

The experiment with low concentrations of $\mathrm{N}$-ammonium (from zero to $5 \mu \mathrm{M}$ ) showed that only green morphs presented significant differences on growth rates when compared to the control (figure 6). Optimum concentration for growth of the DG morph was 1,0 $\mu \mathrm{M} \mathrm{N}$-ammonium while LG morph showed higher growth rates at 1.0 and $4.0 \mu \mathrm{M} \mathrm{N}$-ammonium (figure 6).

Growth rates of the four colour morphs in relation to the increase of $\mathrm{N}$-urea concentration followed kinetic of saturation-type nutrient uptake (figure 7). Growth rates of BR-1 and DG morphs increased at concentrations higher than $5 \mu \mathrm{M} \mathrm{N}$-urea, and the optimal concentrations for growth were 10 and $5 \mu \mathrm{M} \mathrm{N}$-urea, respectively (figure 7).

A comparison among the four morphs indicated that responses to different nitrogen concentrations (nitrate, ammonium, and urea) as well as nitrogen sources (ammonium and urea) showed intraspecific variations (table 2). Besides, the interaction between nitrogen concentrations and sources had significant effects on colour morphs of $H$. musciformis (table 3 ).

Table 1. Bifactorial analysis based on growth rates of colour morphs (BR-1, BR-2, DG, and LG) of Hypnea musciformis cultured in von Stosch and ASP 12-NTA media with different concentrations of N-nitrate. Variables: N-nitrate concentrations (A), and morphs (B). Bold letters/numbers indicate significant effects.

\begin{tabular}{cccrr}
\hline Medium & Effects & Degrees of freedom & \multicolumn{1}{c}{$F$} & \multicolumn{1}{c}{ P } \\
\hline \multirow{4}{*}{ Von Stosch } & A & 2 & 2.81 & 0.0802 \\
& B & $\mathbf{3}$ & $\mathbf{7 3 . 2 7}$ & $<\mathbf{0 . 0 0 0 1}$ \\
& Interaction A/B & 6 & 1.27 & 0.3082 \\
ASP 12-NTA & $\mathbf{A}$ & $\mathbf{2}$ & $\mathbf{6 2 . 4 0}$ & $<\mathbf{0 . 0 0 0 1}$ \\
& $\mathbf{B}$ & $\mathbf{3}$ & $\mathbf{9 9 . 5 6}$ & $<\mathbf{0 . 0 0 0 1}$ \\
& Interaction A/B & $\mathbf{6}$ & $\mathbf{8 . 0 3}$ & $<\mathbf{0 . 0 0 0 1}$ \\
\hline
\end{tabular}


Table 2. Bifactorial analysis based on growth rates of colour morphs (BR-1, BR-2, DG, and LG) of Hypnea musciformis cultured in sterilized seawater with addition of different concentrations of N-nitrate, $\mathrm{N}$-ammonium and $\mathrm{N}$-urea. Variables: Nitrogen concentrations (A), morphs (B). Bold letters/numbers indicate significant effects.

\begin{tabular}{|c|c|c|c|c|}
\hline $\begin{array}{c}\text { Nitrogen sources } \\
\text { (concentrations) }\end{array}$ & Effects & $\begin{array}{c}\text { Degrees of } \\
\text { freedom }\end{array}$ & $F$ & $\mathrm{P}$ \\
\hline \multirow{3}{*}{$\begin{array}{c}\text { Nitrate } \\
(0,5, \ldots 30 \mu \mathrm{M})\end{array}$} & $\mathbf{A}$ & 6 & 2.60 & 0.0289 \\
\hline & B & 4 & 1.87 & 0.1311 \\
\hline & Interaction $\mathbf{A} / \mathbf{B}$ & 24 & 2.07 & 0.0155 \\
\hline \multirow{3}{*}{$\begin{array}{c}\text { Ammonium } \\
(0,5, \ldots 30 \mu \mathrm{M})\end{array}$} & $\mathbf{A}$ & 6 & 16.09 & $<0.0001$ \\
\hline & B & 4 & 9.57 & $<0.0001$ \\
\hline & Interaction $\mathrm{A} / \mathrm{B}$ & 24 & 1.70 & 0.0583 \\
\hline \multirow{3}{*}{$\begin{array}{l}\text { Ammonium } \\
(0,1, \ldots 5 \mu \mathrm{M})\end{array}$} & A & 6 & 8.16 & $<0.0001$ \\
\hline & B & 4 & 1.80 & 0.1605 \\
\hline & Interaction $\mathbf{A} / \mathbf{B}$ & 24 & 2.15 & 0.0232 \\
\hline \multirow{3}{*}{$\begin{array}{c}\text { Urea } \\
(0,5, \ldots 30 \mu \mathrm{M})\end{array}$} & $\mathbf{A}$ & 6 & 10.78 & $<0.0001$ \\
\hline & B & 4 & 4.28 & 0.0048 \\
\hline & Interaction $\mathbf{A} / \mathbf{B}$ & 24 & 1.88 & 0.0307 \\
\hline
\end{tabular}

Table 3. Bifactorial analysis based on growth rates of colour morphs (BR-1, BR-2, DG, and LG) of Hypnea musciformis cultured in sterilized seawater with addition of different concentrations of N-nitrate, $\mathrm{N}$-ammonium and $\mathrm{N}$-urea. Variables: Nitrogen concentrations (A), nitrogen sources (B). Bold letters/numbers indicate significant effects.

\begin{tabular}{cccrr}
\hline Morphs & Effects & Degrees of freedom & \multicolumn{1}{c}{$F$} & \multicolumn{1}{c}{ P } \\
\hline \multirow{3}{*}{ BR-1 } & A & 6 & 2.27 & 0.0545 \\
& B & $\mathbf{2}$ & $\mathbf{8 5 . 5 2}$ & $<\mathbf{0 . 0 0 0 1}$ \\
& Interaction A/B & $\mathbf{1 2}$ & $\mathbf{6 . 2 8}$ & $<\mathbf{0 . 0 0 0 1}$ \\
DG & A & & & \\
& B & $\mathbf{6}$ & $\mathbf{8 . 3 9}$ & $<\mathbf{0 . 0 0 0 1}$ \\
& Interaction A/B & $\mathbf{2}$ & $\mathbf{1 7 8 . 9 8}$ & $<\mathbf{0 . 0 0 0 1}$ \\
& A & $\mathbf{1 2}$ & $\mathbf{5 . 2 1}$ & $<\mathbf{0 . 0 0 0 1}$ \\
BR-2 & B & 6 & & 0.5532 \\
& Interaction A/B & $\mathbf{2}$ & 0.830 & $<\mathbf{0 . 0 0 0 1}$ \\
& A & $\mathbf{1 2}$ & & $\mathbf{0 . 0 0 1 6}$ \\
& B & 6 & 2.52 & 0.0355 \\
LG & Interaction A/B & $\mathbf{1 2}$ & $\mathbf{1 0 5 . 9 7}$ & $<\mathbf{0 . 0 0 0 1}$ \\
& & & $\mathbf{3 . 4 7}$ & $\mathbf{0 . 0 0 1 3}$ \\
\hline
\end{tabular}




\section{VON STOSCH}
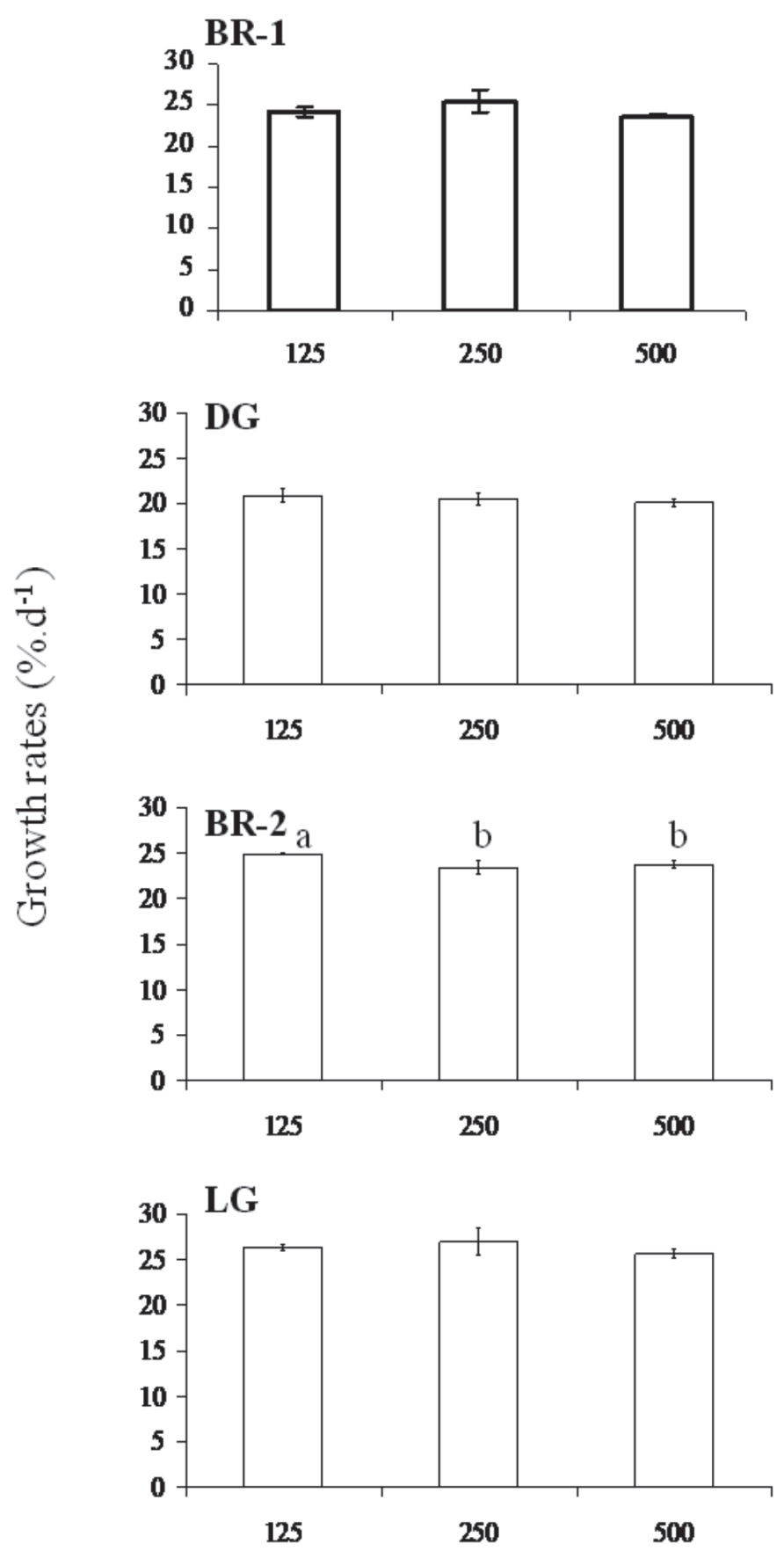

ASP 12-NTA
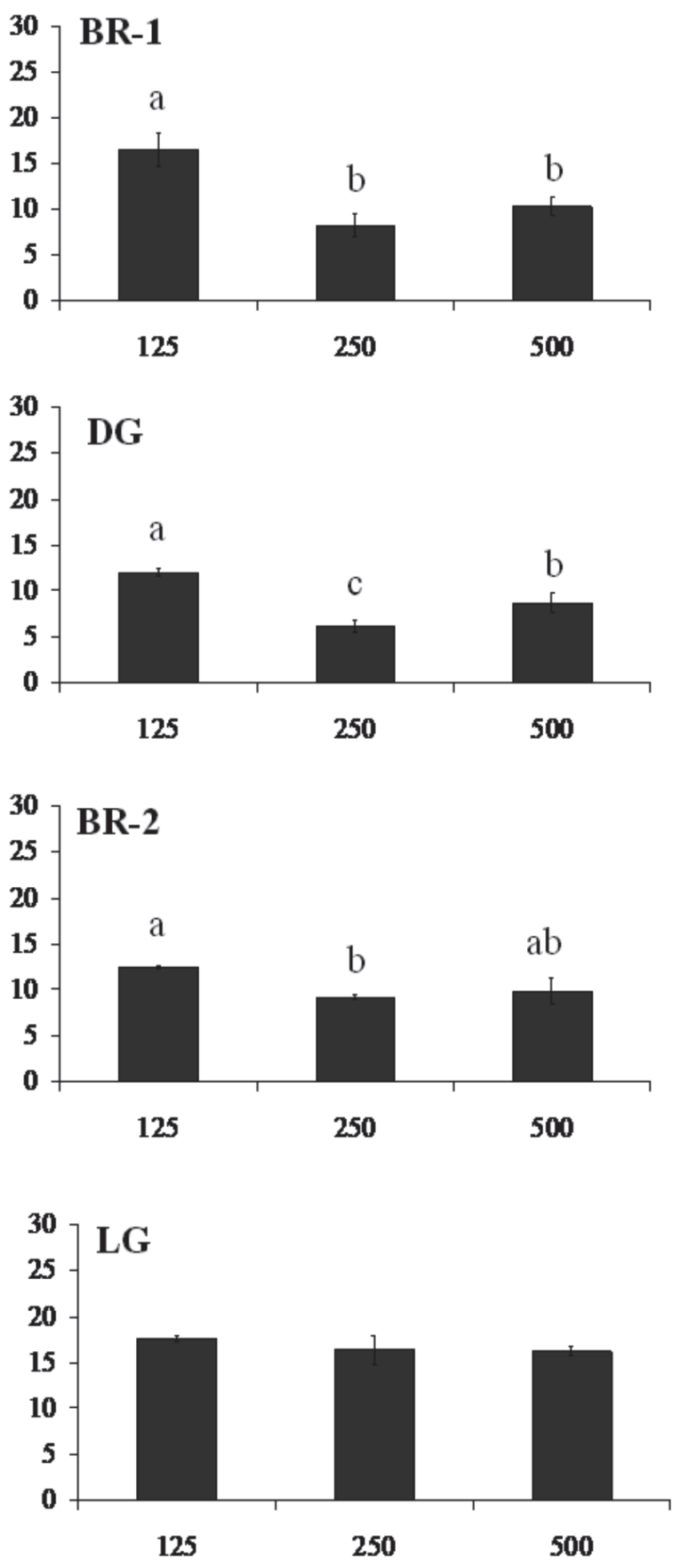

Nitrate concentration $(\mu \mathrm{M})$

Figure 1. Growth rates of brown morphs (BR-1 and BR-2), dark-green morph (DG) and light-green morph (LG) of Hypnea musciformis cultured at different concentrations of N-nitrate in Von Stosch and ASP 12-NTA media. Each data point represents the mean $(\mathrm{n}=3, \pm$ SD). Treatments marked by different letters are significantly different according to ANOVA and Student-Newman-Keuls comparison test $(\mathrm{p}<0.05)$. To BR-2 and LG morphs the data were analyzed by ANOVA on Ranks. 
VON STOSCH

ASP 12-NTA
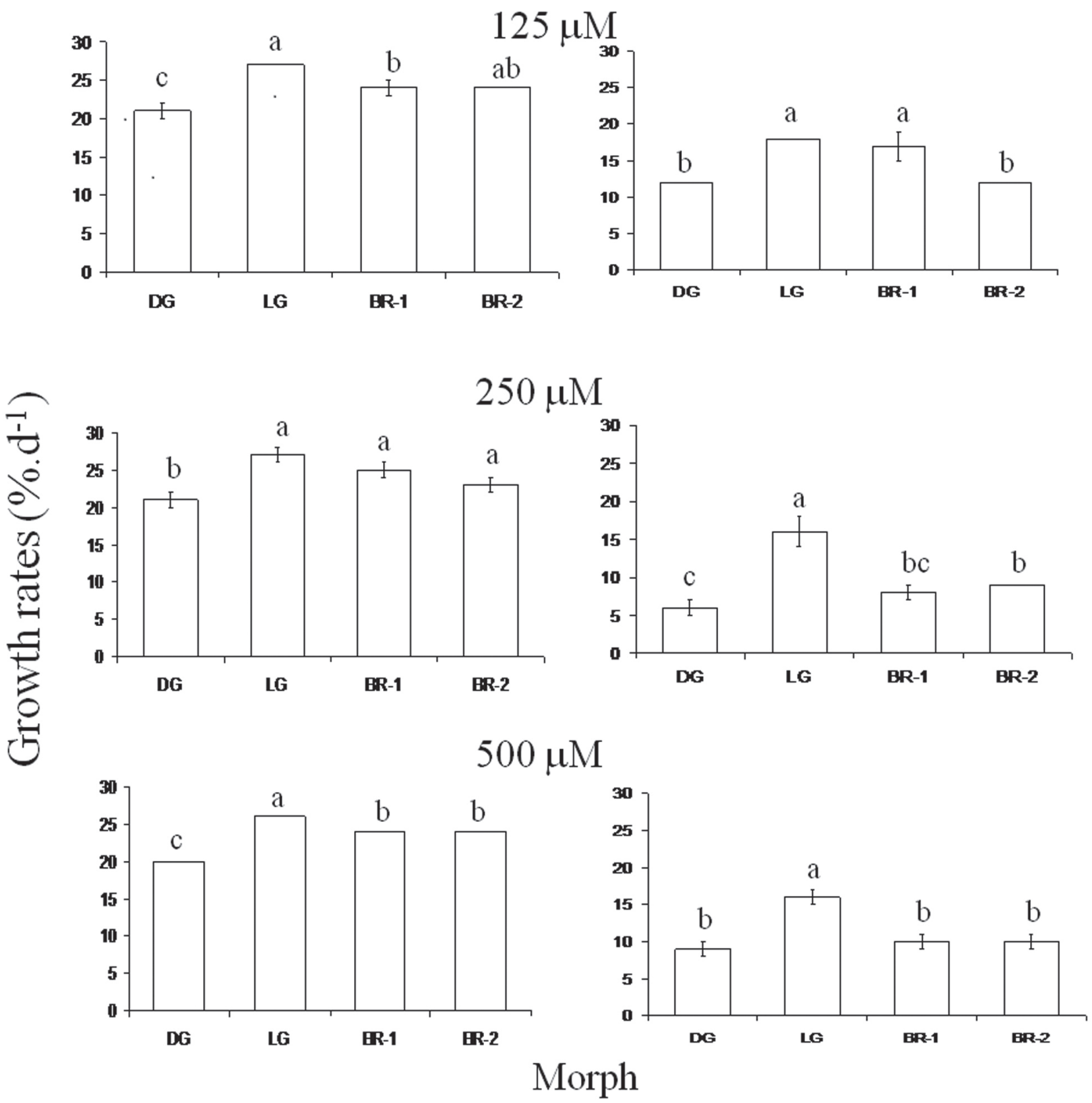

Figure 2. Growth rates of the four morphs of $H$. musciformis (brown morphs, BR-1, BR-2, dark-green morph, DG, and light-green morph, LG) cultured at different concentrations of N-nitrate in Von Stosch and ASP 12-NTA media. Each data point represents the mean $(n=3, \pm \mathrm{SD})$. Treatments marked by different letters are significantly different according to ANOVA and Student-Newman-Keuls comparison test $(\mathrm{p}<0.05)$. 


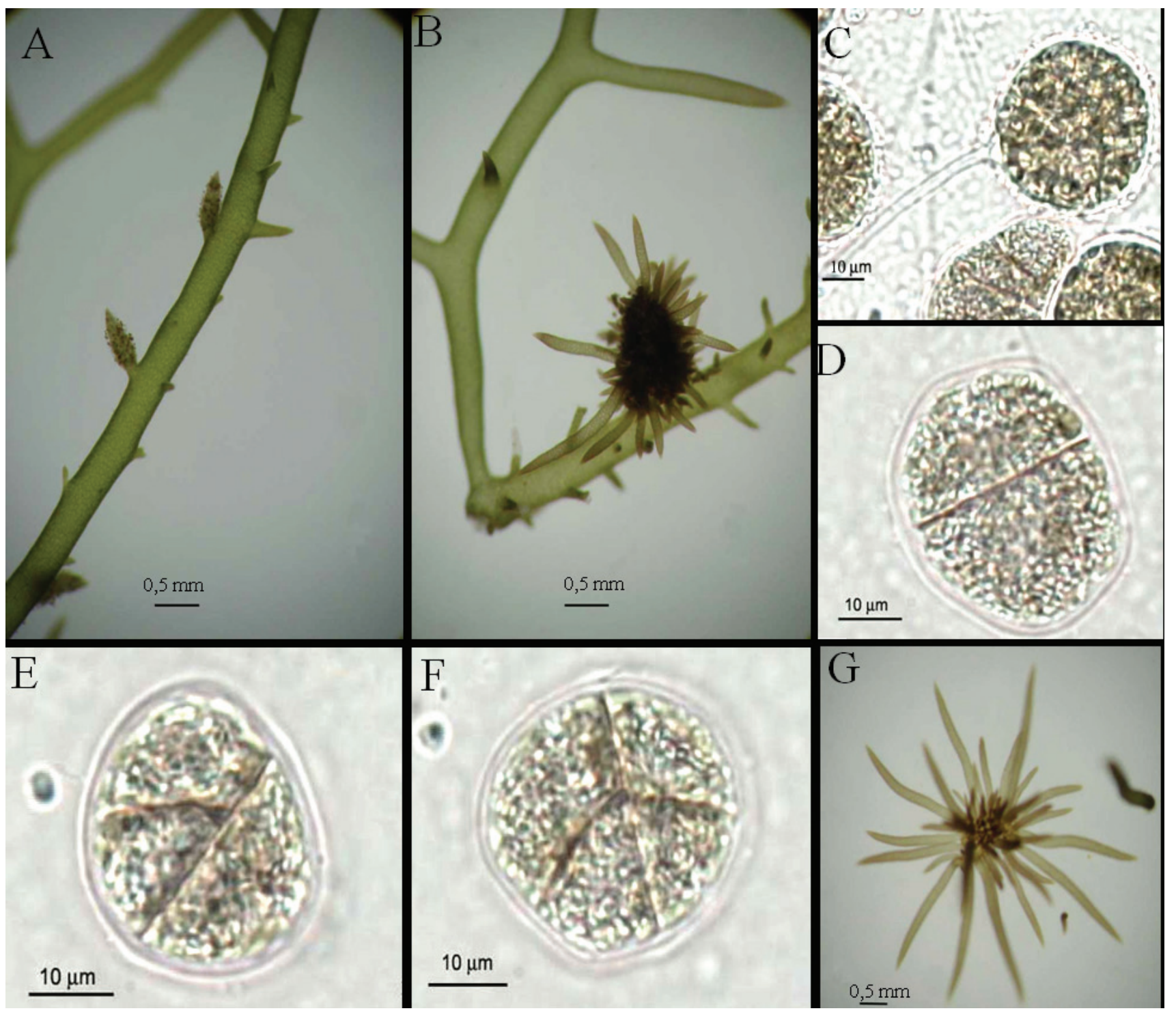

Figure 3. Dark green morph (DG) of H. musciformis cultured at ASP 12-NTA medium with $250 \mu \mathrm{M}$ N-nitrate. A. branch with stichidia; B. germination "in situ", and tetrasporelings growing on mother-plant; C-G. process of tetraspore germination and tetrasporeling development: C. tetrasporeling with hialin hair, D. two-celled tetrasporeling; E. three-celled tetrasporeling; F. four-celled tetrasporeling; G. tetrasporelings after two weeks. 

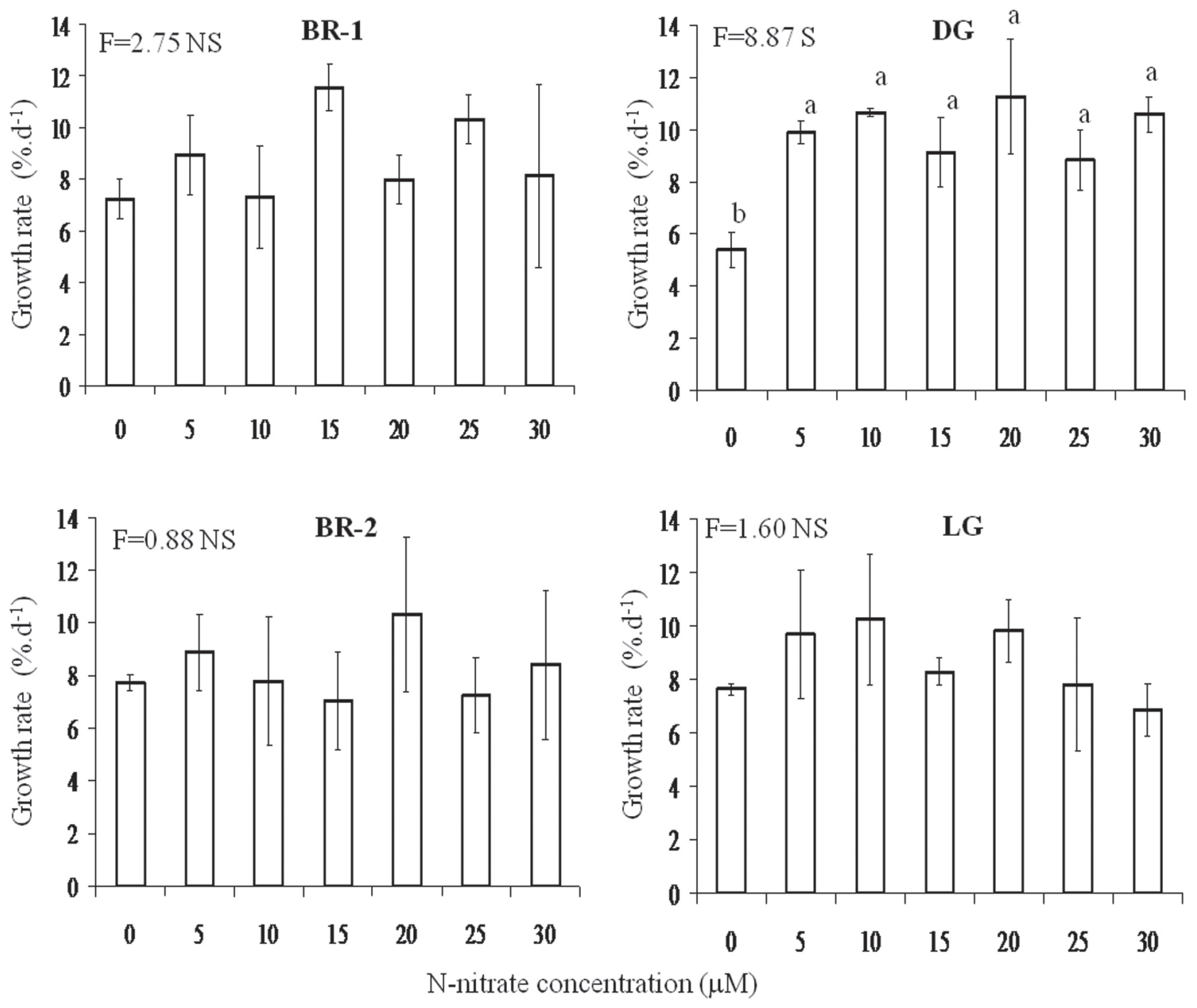

Figure 4. Growth rates of brown morphs (BR-1 and BR-2), dark-green morph (DG) and light-green morph (LG) of H. musciformis cultured at seven different concentrations of $\mathrm{N}$-nitrate. Each data point represents the mean $(\mathrm{n}=3, \pm \mathrm{SD})$. Treatments marked by different letters are significantly different according to ANOVA and Student-Newman-Keuls comparison test $(\mathrm{p}<0.05)$. 

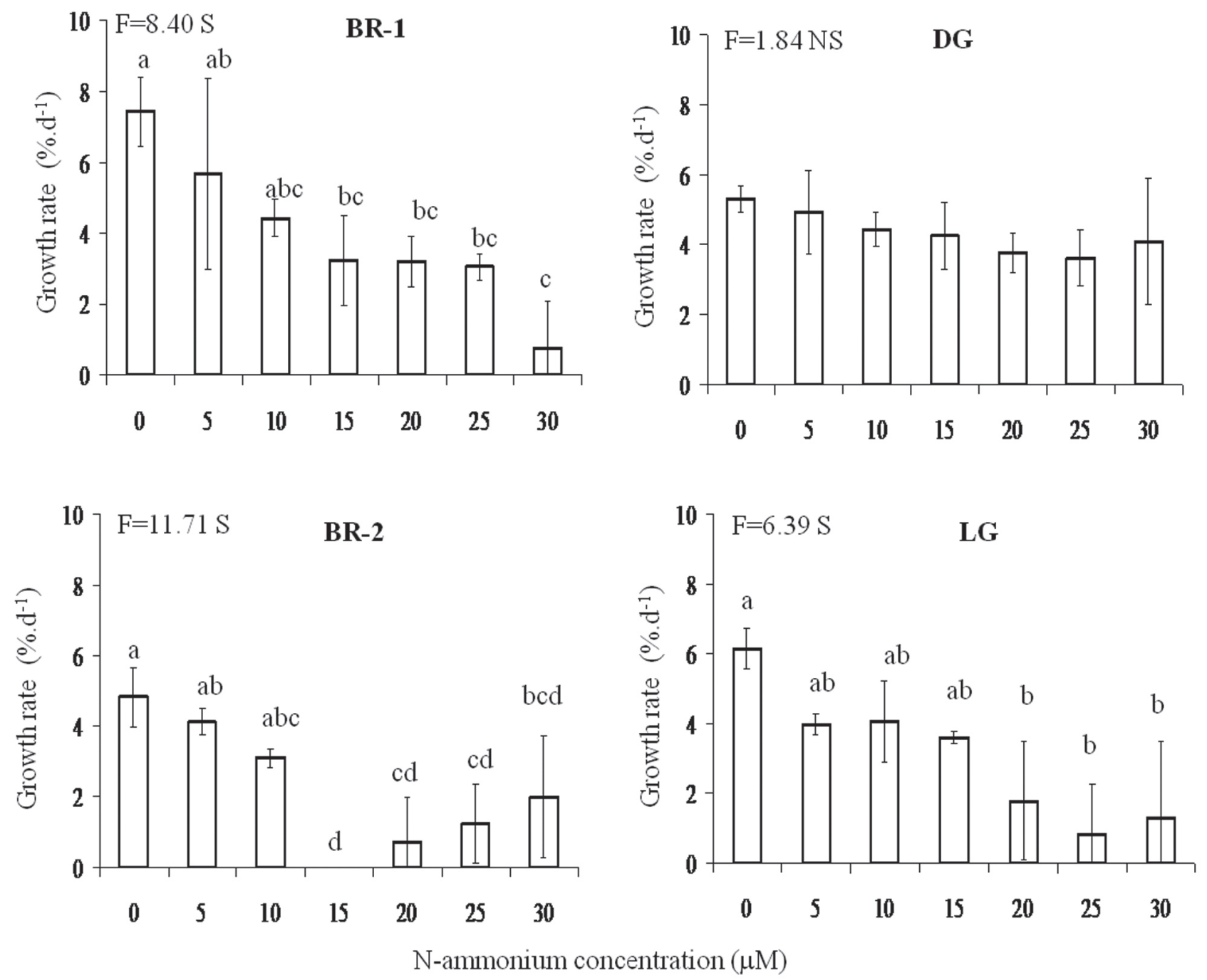

Figure 5. Growth rates of brown morphs (BR-1 and BR-2), dark-green morph (DG) and light-green morph (LG) of H. musciformis cultured at seven different concentrations of $\mathrm{N}$-ammonium. Each data point represents the mean $(\mathrm{n}=3, \pm \mathrm{SD})$. Treatments marked by different letters are significantly different according to the ANOVA and Student-Newman-Keuls comparison test $(\mathrm{p}<0.05)$. To BR-1 morph the data were analyzed by ANOVA on Ranks. 

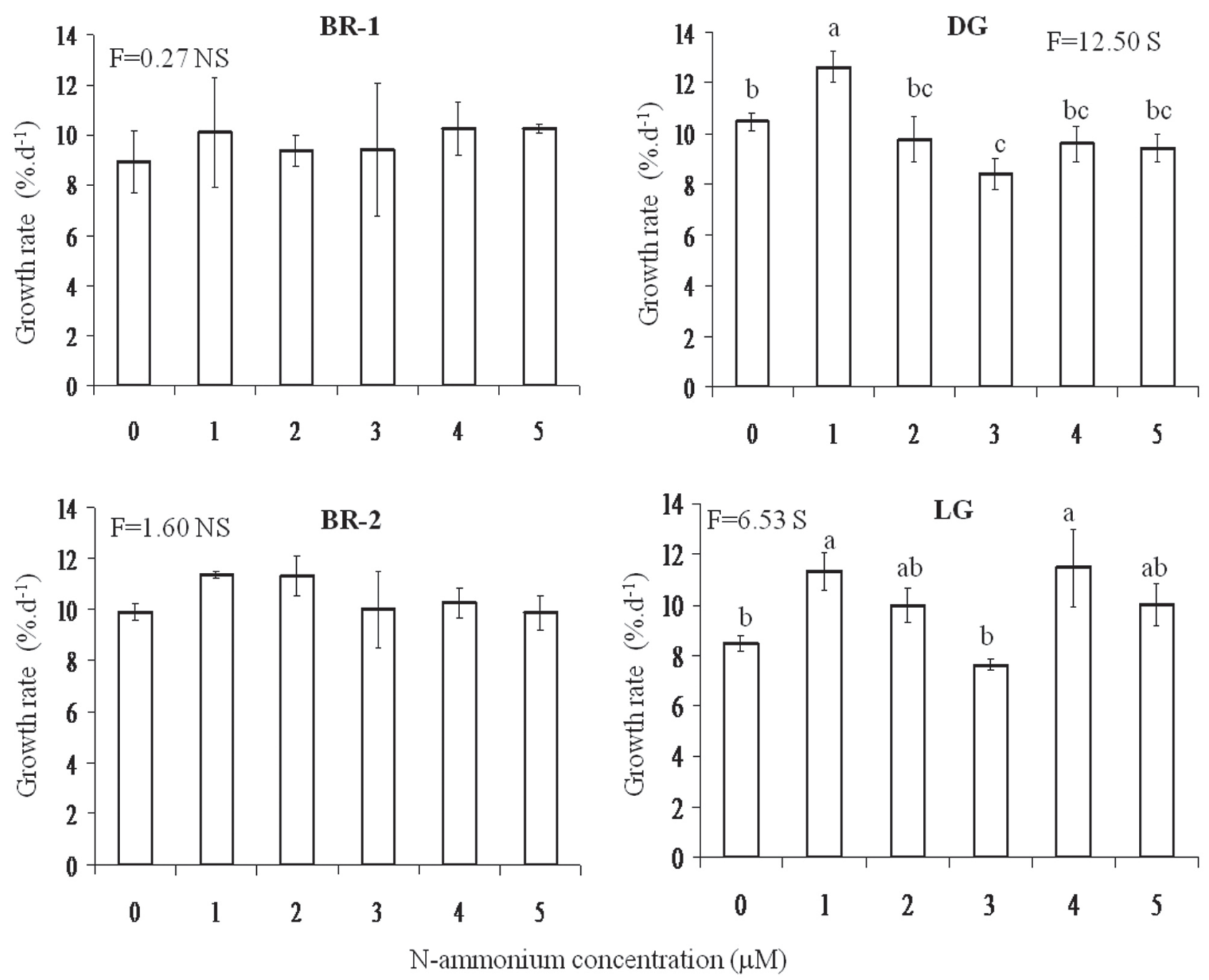

Figure 6. Growth rates of brown morphs (BR-1 and BR-2), dark-green morph (DG) and light-green morph (LG) of H. musciformis cultured at different concentrations of $\mathrm{N}$-ammonium. Each data point represents the mean $(\mathrm{n}=3, \pm \mathrm{SD})$. Treatments marked by the different letter are significantly different according to ANOVA and Student-Newman-Keuls comparison test $(\mathrm{p}<0.05)$. To DG morph the data were analyzed by ANOVA on Ranks. 

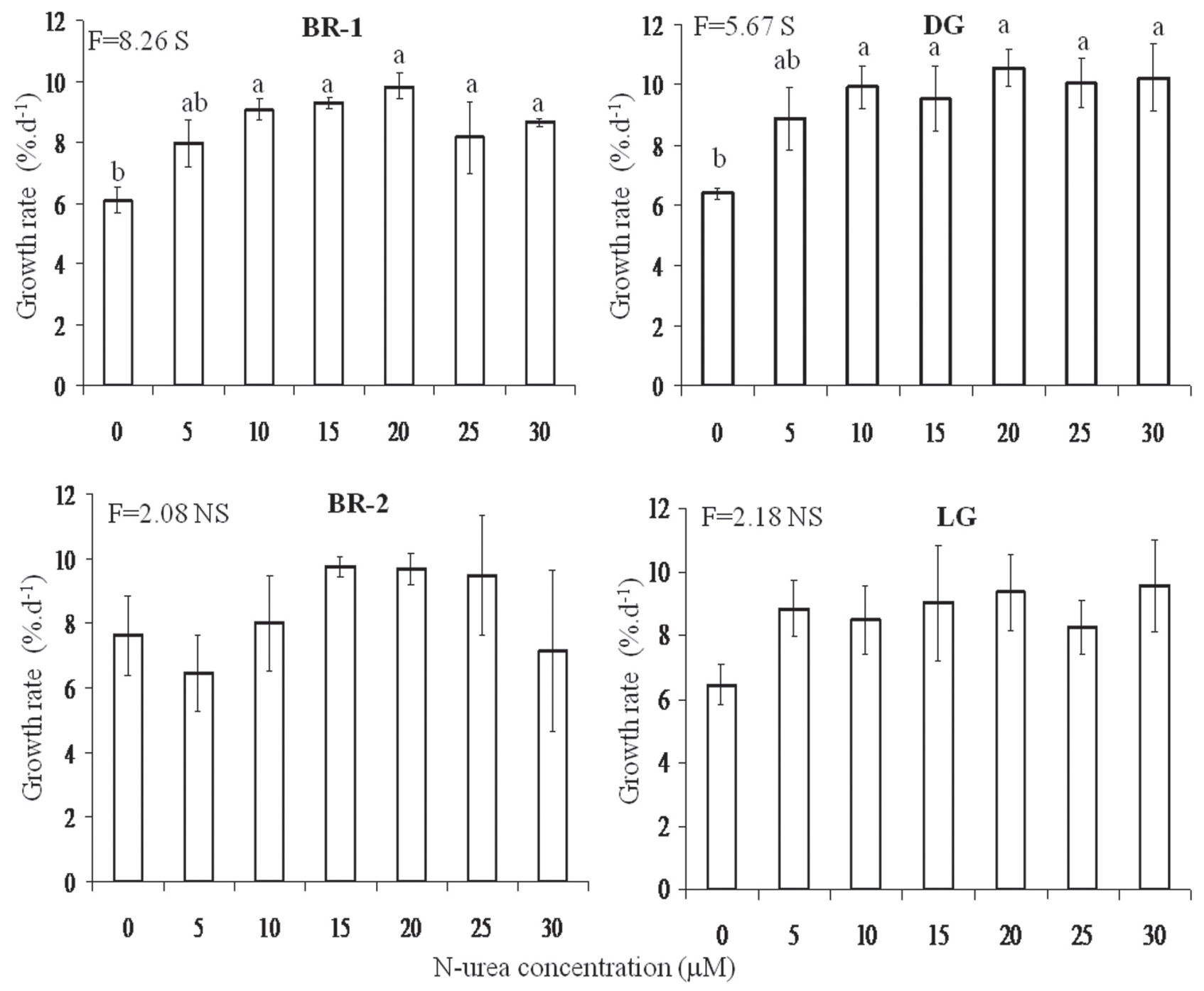

Figure 7. Growth rates of brown morphs (BR-1 and BR-2), dark-green morph (DG) and light-green morph (LG) of H. musciformis cultured at different concentrations of $\mathrm{N}$-urea. Each data point represents the mean $(n=3, \pm \mathrm{SD})$. Treatments marked by different letters are significantly different according to the ANOVA and Student-Newman-Keuls comparison test $(\mathrm{p}<0.05)$. 


\section{Discussion}

Seaweeds are able to use different forms of nitrogen, and each species could have ability to use specific nitrogen sources (Hanisak 1983, Lobban \& Harrison 1994). Considering seaweed growth, three patterns could be observed: 1 . higher growth with nitrate, 2. higher growth with ammonium, and 3. similar growth with nitrate and ammonium (Hanisak 1990). Besides these patterns, some species showed higher growth with addition of organic nitrogen (urea) instead of inorganic nitrogen sources, as observed in the red algae Pterocladiella capillacea (S.G. Gmel.) Santel. \& Hommers. (cited as Pterocladia capillacea, Nasr et al. 1968) and the green algae Ulva fasciata Delile (Mohsen et al. 1974). The red alga Gracilaria cornea did not have preference between organic and inorganic nitrogen sources (Navarro-Angulo \& Robledo 1999).

The four colour morphs of Hypnea musciformis showed higher growth rates with addition of nitrate and urea. However, ammonium inhibited the growth of BR-1, BR-2 and LG morphs, and concentrations higher than $15 \mu \mathrm{M}$ were lethal to $\mathrm{LG}$ and BR-2 morphs. At high concentrations, ammonium could be toxic for some seaweeds (Waite \& Mitchell 1972, Prince 1974), and the four morphs of $H$. musciformis showed similar responses. These results could be explained by the coupling of nitrogen metabolism and photosynthetic pathways (Turpin 1991), and the increase in intracellular ammonium concentration needs a higher carbon skeleton availability for nitrogen assimilation. Probably, intracellular ammonium could not be assimilated by H. musciformis colour morphs, and its accumulation into the cytoplasm decreased the internal $\mathrm{pH}$, what was prejudicial to the cells (Turpin 1991). In contrast, different results were observed by Haines (1976) in a cultivation system, where $H$. musciformis showed higher growth in effluent enriched with ammonium than with nitrate, and ammonium uptake was faster than nitrate uptake (Haines \& Wheeler 1978).

A comparison among the four morphs showed intraspecific variations in relation to nitrate availability in VSES and ASP 12-NTA media; DG and LG morphs showed, respectively, the lowest and the highest growth rates in both culture media. Then, DG morph showed lower growth rates than the BR-1 morph, and the best performance of wild specimens was also observed in the red specimens of Gracilaria birdiae (cited as Gracilaria sp. by Ursi \& Plastino
2001), and in brown specimens of Kappaphycus alvarezii (Doty) Doty ex Silva (Paula et al. 1999). However, different results were observed in BR-2 and LG morphs, since the LG morph (phycoerythrindeficient mutant) had higher growth rate than the BR-2 morph (wild specimen). Similar results were observed for a green variant of Kappaphycus striatum (Schmitz) Doty (Gerung \& Ohno 1997), and for yellowish-brown mutant of Porphyra yezoensis Ueda, which had higher growth than the wild specimen and other colour mutants (Yan et al. 2000).

In the four colour morphs of Hypnea musciformis, relationship between growth rates and urea concentrations corresponds to a saturation curve. Similar results were also observed for the red algae Neoagardhiella bailey (Harvey ex Kützing) Wynne \& Taylor and Gracilaria foliifera (Forsskal) $\mathrm{B} \phi$ rgesen, with half saturation constants $(K s)$ values ranging from 0.2 to $0.4 \mu \mathrm{M}$ of different nitrogen sources, and maximum values of growth rates at nitrogen concentrations up to $1.0 \mu \mathrm{M}$ (DeBoer et al. 1978). However, higher values were observed to young specimens of the brown algae Macrocystis pyrifera (L.) Agardh (from 6 to $15 \mu \mathrm{M}$ ) and the green algae Cladophora aff. albida (Hudson) Kützing $(30 \mu \mathrm{M})$ (Gordon et al. 1981). In the present study, optimum concentration was $5 \mu \mathrm{M}$ N-nitrate for DG morph of $H$. musciformis. Similar results were observed to Laminaria saccharina (L.) J.V. Lamour., which growth rate reached the maximum value at nitrogen concentrations of 5 and $10 \mu \mathrm{M} N$-nitrate (Wheeler \& Weidner 1983). With addition of urea, the optimum concentration was $10 \mu \mathrm{M}$ for BR-1 and DG morphs. Urea is considered a good nitrogen source for many seaweed species, and, generally its assimilation follows saturation kinetics (Thomas \& Harrison 1985).

In conclusion, responses of the four colour morphs showed intraspecific variations in relation to nitrogen sources and concentrations. Moreover, colour morphs of $H$. musciformis could be used as bioindicators of nitrogen pollution in the marine environment by their low tolerance to ammonium.

\section{Acknowledgments}

The authors thank Noemy YamaguishiTomita for collecting the mother-plant, which originated the brown and light-green morphs of Hypnea musciformis. This research was supported 
by a grant provided by Conselho Nacional de Desenvolvimento Científico e Tecnológico (CNPq, Brazil) to NSY, and by a scholarship from Programa Institucional de Bolsas de Iniciação Científica (PIBIC-CNPq, Brazil) to Aline P. Martins.

\section{Literature cited}

Andria, J.R., Vergara, J.J. \& Perez-Llorens, J.L. 1999. Biochemical responses and photosynthetic performance of Gracilaria sp. (Rhodophyta) from Cádiz, Spain, cultured under different inorganic carbon and nitrogen levels. European Journal of Phycology 34: 497-504.

Berchez, F.A.S., Pereira, R.T.L. \& Kamiya, N.F. 1993. Culture of Hypnea musciformis (Rhodophyta - Gigartinales) on artificial substrates attached to linear ropes. Hydrobiologia 260/261: 415-420.

Bird, K.T., Habig, C. \& Debusk, T. 1982. Nitrogen allocation and storage patterns in Gracilaria tikvahiae (Rhodophyta). Journal of Phycology 18: 344-348.

Braga, A.C. \& Yoneshigue-Valentin, Y. 1994. Growth of Laminaria abyssalis (Phaeophyta) at different nitrate concentrations. Phycologia 33: 271-274.

Braga, A.C. \& Yoneshigue-Valentin, Y. 1996. Nitrogen and phosphorus uptake by the Brazilian kelp Laminaria abyssalis (Phaeophyta) in culture. Hydrobiologia 326/327: 445-450.

Chow, F., Capociama, F.V., Faria, R.B.M. \& Oliveira, M.C. 2007. Characterization of nitrate reductase activity in vitro in Gracilaria caudata J. Agardh (Rhodophyta, Gracilariales). Revista Brasileira de Botânica 30: 123-129.

Collén, P.N., Camitz, A., Hancock, R.D., Viola, R. \& Pedersén, M. 2004. Effect of nutrient deprivation and resupply on metabolites and enzymes related to carbon allocation in Gracilaria tenuistipitata (Rhodophyta). Journal of Phycology 40: 305-314.

Costa, V.L. 2005. Diversidade intraespecífica em gametófitos de Gracilaria birdiae (Gracilariales, Rhodophyta): efeitos fisiológicos da concentração de nitrogênio no meio de cultura. Tese de Doutorado, Universidade de São Paulo, São Paulo.

Critchley, A.T. \& Ohno, M. 1998. Seaweed resources of the world. Japan International Cooperation Agency, Yokosuka.
Deboer, J.A., Guigli, H.J., Israel, T.L. \& D'Elia, C.F. 1978. Nutritional studies of two red algae. I. Growth rate as a function of nitrogen source and concentration. Journal of Phycology 14: 261-266.

D'Elia, C.F. \& Deboer, J.A. 1978. Nutritional studies of two red algae. II. Kinetics of ammonium and nitrate uptake. Journal of Phycology 14: 226272.

Donato, R. 2005. Diversidade intraespecífica em linhagens tetrasporofíticas de Gracilaria birdiae (Gracilariales, Rhodophyta): crescimento, caracterização pigmentar, fotossíntese e assimilação de nitrato. Tese de doutorado, Universidade de São Paulo, São Paulo.

Edwards, P. 1970. Illustrated guide to the seaweeds and seagrasses in the vicinity of Porto Aransas, Texas. Contributions to Marine Science, University of Texas at Austin 15: 1-228.

Fujita, R.M. 1985. The role of nitrogen status in regulating transient ammonium uptake and nitrogen storage by macroalgae. Journal of Experimental Marine Biology and Ecology 92: 283-301.

García-Sanchez, M.J., Fernández, J.A. \& Niell, F.X. 1993. Biochemical and physiological responses of Gracilaria tenuistipitata under two different nitrogen treatments. Physiological Plantarum 88: 631-637.

Gerung, G.S. \& Ohno, M. 1997. Growth rates of Eucheuma denticulatum (Burman) Collins et Harvey and Kappaphycus striatum (Schmitz) Doty under different conditions in warm waters of Southern Japan. Journal of Applied Phycology 9: 413-415.

Gordon, D.M., Birch, P.B. \& McComb, A.J. 1981. Effects of inorganic phosphorus and nitrogen on the growth of an estuarine Cladophora in culture. Botanica Marina 24: 93-106.

Granbom, M., Chow, F., Lopes, P.F., Oliveira, M.C., Colepicolo, P., Paula, E.J. \& Pedersén, M. 2004. Characterisation of nitrate reductase in the marine macroalgae Kappaphycus alvarezzi (Rhodophyta). Aquatic Botany 78: 295-305.

Haines, K.C. 1976. Growth of the carrageenanproducing tropical red seaweed Hypnea musciformis in surface water, $870 \mathrm{~m}$ deep water, effluent from a clam mariculture system, and in deep water enriched with artificial fertilizers or domestic sewage. In: F. Perssone \& E. Jaspers (eds.). Proceedings of $10^{\text {th }}$ European Symposium 
on Marine Biology, v. I: Mariculture. Universal Press, Wetteren, pp. 207-220.

Haines, K.C. \& Wheeler, P.A. 1978. Ammonium and nitrate uptake by the marine macrophytes Hypnea musciformis (Rhodophyta) and Macrocystis pyrifera (Phaeophyta). Journal of Phycology 14: 319-324.

Hanisak, M.D. 1983. The nitrogen relationships of marine macroalgae. In: E.J. Carpenter \& D.G. Capone (eds.) Nitrogen in the Marine Environment. Academic Press, New York, pp. 699-730.

Hanisak, M.D. 1990. The use of Gracilaria tikvahiae (Gracilariales, Rhodophyta) as a model system to understand the nitrogen nutrition of cultured seaweeds. Hydrobiologia 204/205: 79-87.

Hurd, C.L., Berges, J.A., Osborne, J. \& Harrison, P.J. 1995. An in vitro nitrate reductase assay for marine macroalgae: optimization and characterization of the enzyme for Fucus gardneri (Phaeophyta). Journal of Phycology 31: 835-843.

Hwang, S.-P.L., Williams, S.L. \& Brinkhuis, B.H. 1987. Changes in internal dissolved nitrogen pools as related to nitrate uptake an assimilation in Gracilaria tikvahiae McLachlan (Rhodophyta). Botanica Marina 30: 11-19.

Iwasaki, H. 1961. The life cycle of Porphyra tenera in vitro. Biological Bulletin 121: 173-187.

Lobban, C.S. \& Harrison, P.J. 1994. Seaweed Ecology and Physiology. Cambridge University Press, Cambridge.

Lopes, P.F., Oliveira, M.C. \& Colepicolo, P. 2002. Characterization and daily variation of nitrate reductase in Gracilaria tenuistipitata (Rhodophyta). Biochemical and Biophysical Research 295: 50-54.

Martínez, B. \& Rico, J.M. 2004. Inorganic nitrogen and phosphorus uptake kinetics in Palmaria palmata (Rhodophyta). Journal of Phycology 40: 642-650.

Martins. A.P., Yokoya, N.S., Carvalho, M.A.M. \& Plastno, E.M. 2008. Effects of kinetin and nitrogen on growth rates, pigment and protein contents of wild and phycoerythrin-deficient morphs of Hypnea musciformis (Rhodophyta). Journal of Applied Phycology (in press). DOI 10.1007/s10811-007-9289-x.

Masuda, J., Yamagishi, Y., Chiang, Y-M., Lewmanomont, K. \& Xi, B. 1997. Overview of Hypnea (Rhodophyta, Hypneacea). In: I.A.
Abbott (ed). Taxonomy of economic seaweeds. California Sea Grant College System, La Jolla, v. 6 , pp. 127-133.

Mohsen, A.F., Khaleafa, A.F., Hashem, M.A. \& Metwalli, A. 1974. Effect of different nitrogen sources on growth, reproduction, amino acid, fat and sugar contents in Ulva fasciata Delile. Botanica Marina 17: 218-222.

Naldi, M. \& Wheeler, P.A. 2002. ${ }^{15} \mathrm{~N}$ measurements of ammonium and nitrate uptake by Ulva fenestrata (chlorophyta) and Gracilaria pacifica (Rhodophyta): comparison of net nutrient disappearance, release of ammonium and nitrate, and ${ }^{15} \mathrm{~N}$ accumulation in algal tissue. Journal of Phycology 38: 135-144.

Nasr, A.H., Bekheet, I.A. \& Ibrahim, R.K. 1968. The effect of different nitrogen and carbon sources on amino acid synthesis in Ulva, Dictyota, and Pterocladia. Hydrobiologia 31: 7-16.

Navarro-Angulo, L. \& Robledo, D. 1999. Effects of nitrogen source, N:P ratio and N-pulse concentration and frequency on the growth of Gracilaria cornea (Gracilariales, Rhodophyta) in culture. Hydrobiologia 398/399: 315-320.

Paula, E.J., Pereira, R.T.L. \& Ohno, M. 1999. Morph selection in Kappaphycus alvarezii var. alvarezii (Solieriaceae, Rhodophyta) using tetraspore progeny. Journal of Applied Phycology 11: 111-121.

Pedersen, A., Kraemer, G. \& Yarish, C. 2004. The effects of temperature and nutrient concentrations on nitrate and phosphate uptake in different species of Porphyra from Long Island Sound (USA). Journal of Experimental Marine Biology and Ecology 312: 235-252.

Phillips, J.C. \& Hurd, C.L. 2004. Kinetics of nitrate, ammonium, and urea uptake by four intertidal seaweeds from New Zealand. Journal of Phycology 40: 534-545.

Plastino, E.M. 2003. Cultivo en laboratorio y selección de cepas en algas rojas (Rhodophyta). In: A. Mansilla, C. Werllinger \& N. Navarro (eds.). Memorias de Curso Internacional de Posgrado y Especialización de Macroalgas em Ambientes Subantárticos. Ediciones Universidad de Magallanes, Punta Arenas, pp. 53-58.

Prince, J.S. 1974. Nutrient assimilation and growth of some seaweeds in mixtures of seawater and secondary sewage treatment effluents. Aquaculture 4: 69-79. 
Rossa, M.M. 1999. A luz como fator de regulação da atividade enzimática da nitrate redutase (NR) e superóxido dismutase (SOD) em Gracilariopsis tenuifrons (Rhodophyta). Dissertação de Mestrado, Universidade de São Paulo, São Paulo.

Taylor, M.W. \& Rees, T.V. 1999. Kinetics of ammonium assimilation in two seaweeds, Enteromorpha sp. (Chlorophyceae) and Osmundaria colensoi (Rhodophyceae). Journal of Phycology 35: 740-746.

Thomas, T.E. \& Harrison, P.J. 1985. Effects of nitrogen supply on nitrogen uptake, accumulation and assimilation in Porphyra perforata (Rhodophyta). Marine Biology 85: 269-278.

Turpin, D.H. 1991. Effects of inorganic N availability on algal photosynthesis and carbon metabolism. Journal of Phycology 27: 14-20.

Ursi, S. \& Plastino, E.M. 2001. Crescimento in vitro de linhagens de coloração vermelha e verde clara de Gracilaria sp. (Gracilariales, Rhodophyta) em dois meios de cultura: análises de diferentes estádios reprodutivos. Revista Brasileira de Botânica 24: 587-594.

Waite, T.D. \& Mitchell, R. 1972. The effect of nutrient fertilization on the benthic alga Ulva lactuca. Botanica Marina 15: 151-156.

Wheeler, W.N. \& Weidner, M. 1983. Effects of external inorganic nitrogen concentration on metabolism, growth and activities of key carbon and nitrogen assimilating enzymes of Laminaria saccharina (Phaeophyceae) in culture. Journal of Phycology 19: 92-96.

Yan, X.-H., Fujita, Y. \& Aruga, Y. 2000. Induction and characterization of pigmentation mutants in Porphyra yezoensis (Bangiales, Rhodophyta). Journal of Applied Phycology 12: 69-81.

Yokoya, N.S. 2000. Apical callus formation and plant regeneration controlled by plant growth regulators on axenic culture of the red alga Gracilariopsis tenuifrons (Gracilariales, Rhodophyta). Phycological Research 48: 133142.

Yokoya, N.S., Plastino, E.M. \& Artel, R. 2003. Physiological responses and pigment characterization of two colour morphs of the carrageenophyte Hypnea musciformis (Rhodophyta). In: A.R.O. Chapman, R.J. Anderson, V.J. Vreeland \& I.R. Davison (eds). Proceedings of the XVII ${ }^{\text {th }}$ International Seaweed Symposium. Oxford University Press, New York, pp. 425-433. 